JPPIPA, Vol.6 No.1 2021
Jurnal Penelitian Pendidikan IPA
htt//journal.unesa.ac.id/index.php/jppipa

\title{
DEVELOPMENT OF AUGMENTED REALITY MEDIA ON BEE METAMORPHOSIS (Apis Sp.)
}

Ospa Pea Yuanita Meishanti ${ }^{1}$, Zaidatur Roziqo ${ }^{2}$,

${ }^{1,2}$ Biology Education Study Programme, Faculty of Education , KH. A. Wahab Hasbullah University of

East Java, Indonesia.

\begin{abstract}
Educators as implementers of education do not only learn to be able to master the material being taught. Educators must also be able to be creative in developing innovative, varied, interesting, contextual learning media, and adapted to the level of student needs, one of which can be through media development. The learning media itself is a tool that can connect between educators and students in the learning process, providing information and transmitting messages. From this, the research developed Augmented Reality with material about the metamorphosis of bees, using a card and then scanning it using an application. If in Augmented Reality (AR) society this is often found in snacks in the form of cards as gifts from these snacks, then we are asked to scan through the application listed on the card. This study has a goal in developing AR media, among others, to find out from learning media expert and material experts whether AR media is used in the learning process, and to find out how attractive this media is. The method in developing this media uses the ADDIE, namely Analysis by analyzing material and analyzing students, designing by designing then The software used to create media is Vuforia which can be accessed through the website, and Unity Game Engine, development by testing the feasibility of the media, and implementation with the aim of knowing the interesting of the media. Material expert results of AR $88 \%$ with criteria from media experts were very feasible, media experts validated with $80.00 \%$ the criteria obtained were feasible, and the media was very attractive $88.80 \%$. From these results, Augmented Reality bee metamorphosis media is feasible and interesting to support learning.
\end{abstract}

Keywords: Development, Augmented Reality (AR), Bee metamorphosis

(C) 2021 Universitas Negeri Surabaya

${ }^{1}$ Correspondence Address:

Biology Education Study Programme, Faculty of Education, University of KH. A. Wahab Hasbullah

E-mail: ospapea@unwaha.ac.id 


\section{INTRODUCTION}

Raden Mas Soewardi Soerjaningrat or commonly known as Ki Hajar Dewantara who is the father of Indonesian national education stated that education is a condition for the growth and development of children, in the sense that education guides all natural resources that exist in children, making them as humans, members of society, obtaining the highest safety and happiness. (Sugiarta, et al. 2019). Education is one form of embodiment of cultural needs and dynamic human development (Meishanti, 2020). (Permen No. 22, 2016) Law Number 20 of 2003 in the National Education System, Article 1 number 1 Education is a conscious effort and conscious planned to create a learning atmosphere and about learning process so that students actively develop their potential to have spiritual strength, selfcontrol, intelligence, morals, noble values, as well as skills needed by self, society, nation, and state. Educators as implementers of education are not only expected to be able to master the material to be taught. Educators also expected to be creative, innovative, varied, interesting learning, contextual learning media, and according to the level of student needs, because these things will determine the competencies that will be achieved and possessed by students after the learning process takes place. So for about whole process of education in schools most of the learning and learning activities are successful or not and student learning achievement depends on how the learning process is obtained (Meishanti, 2018).

The learning process on biological material itself is a science that studies natural phenomena that can be formulated empirically. In the quality of biology learning education is very necessary and focuses on increasing students' knowledge about themselves and their surroundings (Khoirudin, 2016). Biology learning is able to equip students how to know concepts, facts and must be able to provide and build thinking skills. Student daily test scores from observations of MTs Al-Ihsan Kalijaring Jombang on the growth and development of the metamorphosis submaterial showed that $55 \%$ of the students had not finished. The researcher also conducted a needs analysis in the form of a questionnaire to students about the difficulties in learning the material. The results of the needs analysis conducted in July 2020 showed that the cause of student learning difficulties was due to the many Latin terms and the absence of interesting learning media, so that it makes students' reading interest in textbooks also quite low. This is in accordance with the results of the 2018 PISA survey regarding the low interest in reading students in Indonesia, with a score of 371 and ranking 74 out of a total of 79 countries surveyed (Permana, 2019). Thus, these problems must be addressed immediately. Therefore, researchers will develop Augmented Reality learning media on bee metamorphosis.

The purpose of using media in learning as an intermediary between an educator and a student in the submit learning process, provide information and transmit to messages so that to create a effective and efficient learning process. And than if the learning on process does not use media, so there is not learning process (Mustaqim, 2016). One form of learning media is computer technology-based learning media such as Augmented Reality (AR). (Mustika, 2015) states Augmented Realty, AR users can see the real world in their environment using computergenerated virtual objects. So Augmented Reality is a concept about combining between virtual reality with the reality of the world, then 2-dimensional (2D) or maybe 3-dimensional (3D) virtual objects look real and blend like the real world AR was first implemented by Ivan Sutherland in 1962. Augmented Reality as a methodology has also been developed by various parties so that it can be implemented in various devices. The application of Augmented Reality also does not require special enhancements which generally require a lot of money and time for the purchase and installation process (Young, 2015). Researchers want to take advantage of the advantages of AR to help visualize abstract biological concepts to be more intuitive to improve students' understanding in describing an object. Augmented Reality allows users to see the real world and the virtual world simultaneously (Ahmadi dkk, 2017). The development of Augmented Reality media is expected to increase students' interest in studying bee metamorphosis material that has never been used by other researchers. Augmented Reality learning media developed is honeybee metamorphosis (Apis sp.).

This development research has the aim of describing the feasibility of Augmented Reality media and than to see student responses to the interesting bee metamorphosis AR media.

\section{METHOD}

This type of research is development research with the type of quantitative data in the form of scores and qualitative data namely suggestions and input from several subjects through a response questionnaire to Augmented Reality (AR) Media..

Augmented Reality media design on bee metamorphosis is an individual trial and small group test. This individual trial was carried out to 
media experts and material experts to find out the feasibility of the media to be developed, while the Small group test was conducted to students from MTs Al-Ihsan Kalijaring which aims to knowing the level of interesting of the product to be developed. The subjects in this development research are media experts, namely media expert lecturers, material experts, namely MTs teachers who teach science, and $7^{\text {th }}$ grade students of MTs Al-Ihsan Kalijaring on Jombang.

This developer research uses an instrument in the form of a questionnaire to collect the data that will be needed, including individual data collection instruments in the form of a teacher needs questionnaire and students, a media expert validation sheet, a material expert validation sheet. Meanwhile, for small group trials, student response questionnaires were used.

The research method uses the ADDIE development model with 5 stages, namely $\mathrm{A}$ is Analysis, D is Design, then D is Development, I to Implementation and then $\mathrm{E}$ to Evaluation. At the analysis stage, the activities to analyze the need for Augmented Reality (AR) media. The design stage is designing learning media after analysis then designing a storyboard.

AR development uses the ADDIE development model (Analysis-Design-DevelopImplement-Evaluate) which was developed by Reiser and Mollenda in the 1990s. is a generic instructional design model that serves as a guide in building training program tools and infrastructure that is effective, dynamic and supports independent training performance. Thus can helps training instructors in managing training and learning (Jauhari, 2013).

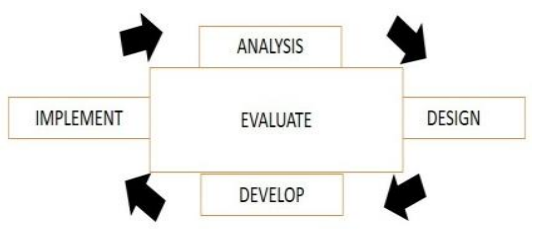

Figure 1. ADDIE Development Model Stages

The next step is to develop learning media from storyboards that have been made and validate the Augmented Reality learning media of bee metamorphosis by media experts from University $\mathrm{KH}$ A. Wahab Hasbullah and a material expert from the science teacher at MTs Al-Ihsan Kalijaring Jombang. The next implementation stage is to conduct trials on students to determine the interesting of AR media on bee metamorphosis material.
The data analysis technique with expert validation and student responses uses the following formula:

$$
P=\frac{\sum x}{\sum x_{i}} x 100 \%
$$

Explanation:
$\begin{array}{ll}\mathrm{P} x= & \text { Percentage of eligibility/attractiveness } \\ \Sigma x & \text { The number of scores obtained from validators } \\ & \text { or respondents (students) }\end{array}$
$x_{2}=$ The maximum number of scores expected

$\sum x_{\overrightarrow{\mathrm{i}}}=$ The maximum number of scores expected

Table 1. Qualification of Validation Result Assessment and Student Response

\begin{tabular}{ccc}
\hline Score & Expert & Student response \\
\hline $81-100$ & Very feasible & Very interesting \\
$61-80$ & feasible & interesting \\
$41-60$ & Quite feasible & less attractive \\
$21-40$ & less fesiable & not attractive \\
$0-20$ & not fesiable & very unattractive \\
\hline \multicolumn{3}{c}{ (Source: Modification from Riduwan, 2012) }
\end{tabular}

\section{RESULTS AND DISCUSSION}

From the ADDIE development model, here are the results and discussion of Augmented Reality media on bee metamorphosis:

\section{Analysis}

The development of AR media at the analysis stage for bee metamorphosis is to analyze the needs in the development of Augmented Reality media in learning. The development of Augmented Reality (AR) media at this analysis stage begins with problems in the learning and media used is less interesting, After analyzing the problems that occurred, so that media that attracted students' interest in learning was developed, the researchers developed Augmented Reality (AR) metamorphosis media in bees.

\section{Design}

Designing instructional media is a step that will be taken after conducting a needs analysis. The initial planning activities carried out by researchers were designing the conceptual framework of Augmented Reality (AR), and compiling a storyboard of the Augmented Reality display.

In the Augmented Reality bee metamorphosis media that will be developed, it contains the original image of the bee metamorphosis and can be operated on mobile phones with a minimum Android operating system 4.4 (Kitkat).

The feature that will be displayed in Augmented Reality metamorphosis of bees is a 2dimensional image of a bee that can display video and audio after the user identifies the image pattern through an android phone of at least version 4.4 (Kitkat), which on the android phone 
has provided an Augmented Reality application in it.

The software used to create Augmented Reality media is Vuforia which can be accessed through the website, and a Unity Game Engine. As for the hardware required is a laptop, an Android-based smartphone with a minimum specification of $600 \mathrm{MHz}$ Processor, Display 256K colors; 480 x 320 pixels, Internal Memory $512 \mathrm{MB}$ ROM and $512 \mathrm{MB}$ RAM, External Memory micro SD 32GB, used to Audio MP3/AAC+/WAV/WMA player, than Video MP4 or H.264 player, HSDPA Connectivity namely 3G; GPRS; WiFi, Operating System Android OS - version 4.4 Kitkat, then used
HTML Browser, and then CMOS Camera; 5.0 Megapixels (Saputro, 2014).

\section{Development}

The ADDIE model at the development stage, namely the conceptual framework stage is realized into a product that is ready to be implemented.

Augmented Reality (AR) learning media on bee metamorphosis was validated by 2 validators, namely media expert, material experts, and 5 respondents from MTs Al-Ihsan Kalijaring Jombang. The presentation of research data from media expert validators can be seen in Table 2 and media expert validators in Table 4.

Table 2. Media Validation Results Table

\begin{tabular}{|c|c|c|c|c|c|}
\hline \multirow[t]{2}{*}{ Number } & \multirow[t]{2}{*}{ Criteria } & \multicolumn{3}{|c|}{ Score } & \multirow[t]{2}{*}{ Explanation } \\
\hline & & $\mathbf{X}$ & $\mathbf{X i}$ & $\%$ & \\
\hline 1. & $\begin{array}{l}\text { Effectiveness and efficiency of media } \\
\text { development and use of learning media }\end{array}$ & 3 & 5 & 60 & Quite feasible \\
\hline 2. & $\begin{array}{l}\text { Augmented Reality (AR) media is suitable } \\
\text { for use }\end{array}$ & 4 & 5 & 80 & feasible \\
\hline 3. & $\begin{array}{l}\text { Easy to operate Media Augmented Reality } \\
\text { (AR) }\end{array}$ & 5 & 5 & 100 & Very feasible \\
\hline 4. & $\begin{array}{l}\text { Media Augmented Reality (AR) in its use is } \\
\text { easy to understand }\end{array}$ & 5 & 5 & 100 & Very feasible \\
\hline 5. & Interesting pictures or videos & 4 & 5 & 80 & feasible \\
\hline 6. & Audio is clear & 4 & 5 & 80 & feasible \\
\hline 7. & $\begin{array}{l}\text { Attractive visuals (including: appearance, } \\
\text { colors and fonts) }\end{array}$ & 4 & 5 & 80 & feasible \\
\hline 8. & Creative in expressing ideas and ideas & 3 & 5 & 60 & Quite feasible \\
\hline & Total & 32 & 40 & $\begin{array}{c}80.00 \\
\%\end{array}$ & feasible \\
\hline
\end{tabular}

Explanation:

$X=$ Scores from Media Experts

$\mathrm{Xi}=$ Maximum Score

The total answers obtained from the media experts were 32 and the maximum score of all answers was 40 , so that the overall score obtained from the the results of the media expert validation obtained an average value of $80.00 \%$ with the appropriate media assessment criteria media feasible. Effective and efficient aspects in the development and use of Augmented Realty (AR) media in learning as well as creative aspects in expressing ideas with an average rating score of $60 \%$ with the criteria of "fairly feasible". For media aspect Augmented Reality (AR) is feasible, the image or video aspect is attractive, the audio aspect is clear, and the visual aspect is attractive (including: appearance, color, and letters) getting an average score of $77,78 \%$. From the assessment of this media expert, it can be concluded that there is a need for further improvements in terms of AR media so that the media can be more feasible to be applied in learning activities. Criticisms and suggestions from media experts, namely the Augmented Reality (AR) card are designed like playing cards with full color front and back so that they attract attention / are seen. Suggestions from media experts, it is necessary to carry out several evaluations which can be seen from Table 3 .

Table 3. Revised Results Based on Expert Advice

Number Revised Points Visualization

\begin{tabular}{ll}
\hline 1. $\quad$ AR card & - AR cards use thicker paper \\
& - Front and rear view is made full color \\
& - The edge of the card is made curved (not sharp) \\
\hline
\end{tabular}




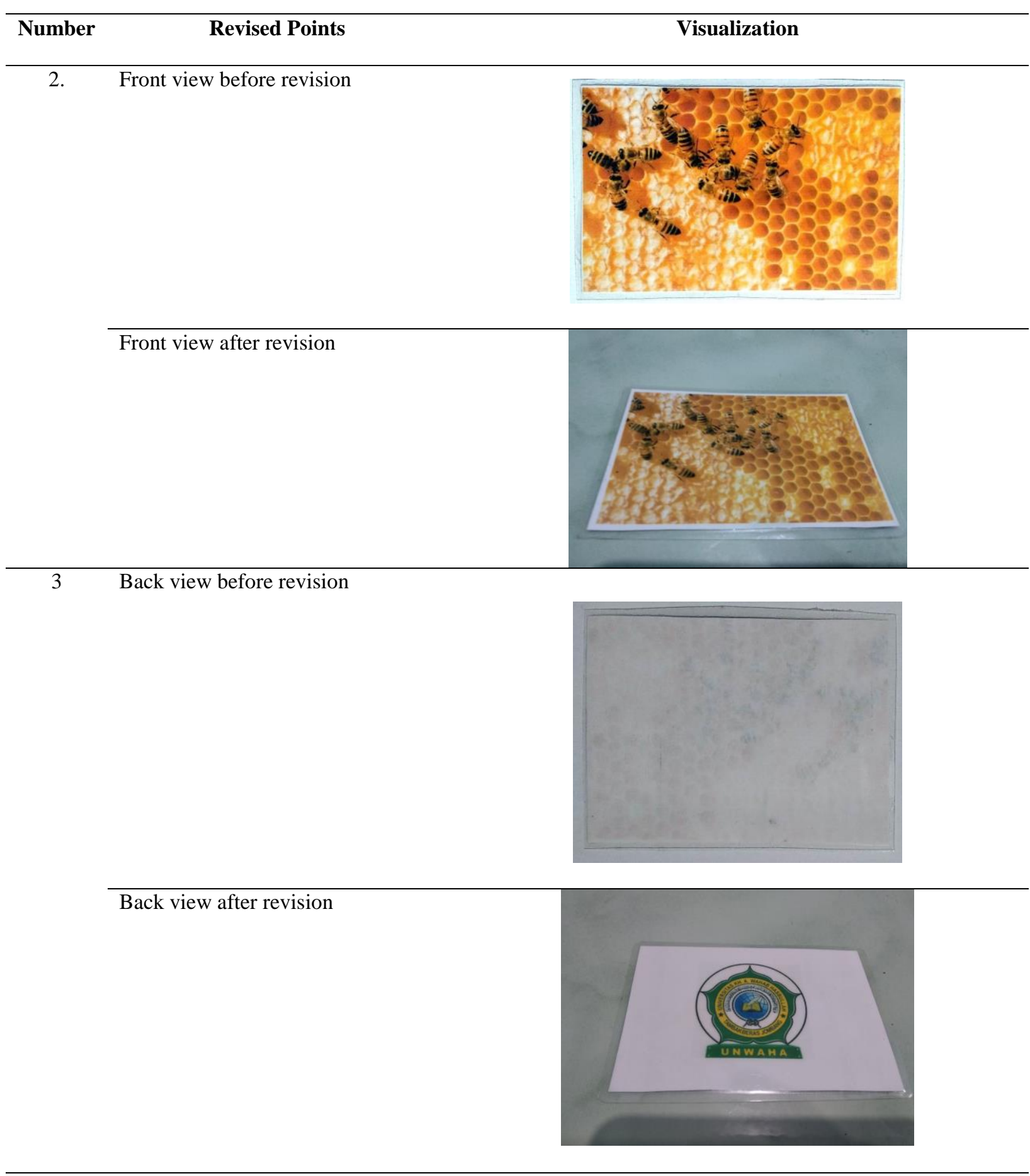

The revision, which is a suggestion from media experts, concludes that a good media is a media that can effectively and efficiently develop and use processes in learning and creative. Aspects in ideas as well as pouring ideas are needed so as to increase students' interest in learning This is in accordance with (Miarso's statement in Mahmun,
2012) which states that one thing that must be done by teachers in using effective learning media is to search for, find, then choose media that can meet student needs and also can attract students' interest in learning. The results of material expert validation can be seen in table 4 . 
Table 4. Data on Assessment Results by Material Experts

\begin{tabular}{|c|c|c|c|c|c|}
\hline \multirow[t]{2}{*}{ Number } & \multirow[t]{2}{*}{ Criteria } & \multicolumn{3}{|c|}{ Score } & \multirow[t]{2}{*}{ Explanation } \\
\hline & & $\mathbf{X}$ & $\mathbf{X i}$ & $\%$ & \\
\hline 1. & $\begin{array}{l}\text { Material according to KI/KD } 3.2 \text { Analyzing } \\
\text { developmental systems in plants and animals } \\
\text { as well as the application of technology to } \\
\text { plant and animal reproductive systems. } \\
\text { (Curriculum 2013) }\end{array}$ & 5 & 5 & 100 & Very feasible \\
\hline 2. & $\begin{array}{l}\text { The material presented is in accordance with } \\
\text { the learning objectives }\end{array}$ & 4 & 5 & 80 & feasible \\
\hline 3. & The clarity of the material presented & 4 & 5 & 80 & feasible \\
\hline 4. & Convey the material well & 4 & 5 & 80 & feasible \\
\hline 5. & Drawings and concepts in accordance with KD & 5 & 5 & 100 & Very feasible \\
\hline 6. & Complete bee metamorphosis process & 5 & 5 & 100 & Very feasible \\
\hline 7. & Sequential bee metamorphosis process & 5 & 5 & 100 & Very feasible \\
\hline 8. & Language according to the EYD & 4 & 5 & 80 & feasible \\
\hline 9. & Language is easy to understand & 4 & 5 & 80 & feasible \\
\hline 10. & Can motivate students & 4 & 5 & 80 & feasible \\
\hline & Total & 44 & $\mathbf{5 0}$ & 88.00 & Very feasible \\
\hline
\end{tabular}

Explanation:

$\mathrm{X}=$ Scores from Material Experts

$\mathrm{Xi}=$ Maximum Score

The total answers obtained from the media experts were 44 and the maximum score of the overall answers was 50, so from the overall score obtained from the media experts above, it obtained with the average value $88.00 \%$ with very feasiblelop assessment criteria. Aspects of material delivered by AR media are in accordance with learning objectives, there are aspects of clarity of material delivered, in terms of good material delivery, linguistic aspects according to EYD, linguistic aspects are easy to understand for AR media users, and AR media can motivate students to learn more active, so that the overall score on the material expert validation get a score assessment with an average of $80 \%$ with feasible assessment criteria. From this assessment, it can be concluded that there needs to be further improvements in terms of material in order to be more feasible to apply in the learning process. Criticism and suggestions from material experts are to better communicate with students.

\section{Implementation}

In the design stage, the media will be developed and implemented like a real situation, namely in the classroom. The implementasi of Augmented Reality media is applied to actual conditions, then asks students to provide responses on the implementation of Augmented Reality media through a questionnaire that aims to determine the attractiveness of the media. For the trial of Augmented Reality Media, bee metamorphosis was carried out on students of MTs Al-Ihsan Kalijaring Jombang. Student responses to Augmented Realty media can be seen in Table 5 the results of student responses.

Table 5. Student Response Questionnaire Results

\begin{tabular}{|c|c|c|c|c|c|c|}
\hline \multirow[t]{2}{*}{ Number } & \multirow[t]{2}{*}{ Aspect } & \multirow[t]{2}{*}{ Criteria } & \multicolumn{3}{|c|}{ Score } & \multirow[t]{2}{*}{ Explanation } \\
\hline & & & $\sum \mathbf{X}$ & $\sum \mathbf{X i}$ & $\%$ & \\
\hline \multirow[t]{4}{*}{1} & \multirow[t]{4}{*}{ Theory } & $\begin{array}{l}\text { I easily understand the material } \\
\text { in Augmented reality (AR) }\end{array}$ & 4,20 & 5,00 & 84,00 & Very interesting \\
\hline & & $\begin{array}{l}\text { The material on Augmented } \\
\text { Reality (AR) is clear }\end{array}$ & 4,00 & 5,00 & 80,00 & Interesting \\
\hline & & $\begin{array}{l}\text { The bee metamorphosis in } \\
\text { Augmented Reality (AR) is } \\
\text { more interesting }\end{array}$ & 5,00 & 5,00 & 100,00 & Very interesting \\
\hline & & Average & 4,40 & 5,00 & 88,00 & Very interesting \\
\hline \multirow[t]{2}{*}{2.} & \multirow[t]{2}{*}{ Display } & $\begin{array}{l}\text { The appearance and color } \\
\text { composition of Augmented } \\
\text { Reality (AR) media is attractive }\end{array}$ & 4,20 & 5,00 & 84.00 & Very interesting \\
\hline & & $\begin{array}{l}\text { Display clear Augmented } \\
\text { Reality (AR) media images and }\end{array}$ & 4,20 & 5,00 & 84,00 & Very interesting \\
\hline
\end{tabular}




\begin{tabular}{|c|c|c|c|c|c|c|}
\hline \multirow[t]{6}{*}{ Number } & \multirow[t]{6}{*}{ Aspect } & \multirow[t]{2}{*}{ Criteria } & \multicolumn{3}{|c|}{ Score } & \multirow[t]{2}{*}{ Explanation } \\
\hline & & & $\sum \mathbf{X}$ & $\sum \mathbf{X i}$ & $\%$ & \\
\hline & & \multicolumn{5}{|l|}{ videos } \\
\hline & & $\begin{array}{l}\text { The animation display in } \\
\text { Augmented Reality (AR) media } \\
\text { is interesting }\end{array}$ & 4,40 & 5,00 & 88,00 & Very interesting \\
\hline & & $\begin{array}{l}\text { The display and text in } \\
\text { Augmented Reality (AR) media } \\
\text { are clear and easy to read }\end{array}$ & 4,20 & 5,00 & 84,00 & Very interesting \\
\hline & & Average & 4,25 & 5,00 & 85,00 & Very interesting \\
\hline \multirow[t]{3}{*}{3.} & \multirow[t]{3}{*}{ Language } & $\begin{array}{l}\text { Media Augmented Reality (AR) } \\
\text { uses Indonesian language rules } \\
\text { that are good and correct }\end{array}$ & 4,40 & 5,00 & 88,00 & Very interesting \\
\hline & & $\begin{array}{l}\text { The language used in the Media } \\
\text { Augmented Reality (AR) is } \\
\text { simple and easy to understand }\end{array}$ & 5,00 & 5,00 & 100,00 & Very interesting \\
\hline & & Average & 4,70 & 5,00 & 94,00 & Very interesting \\
\hline \multirow[t]{4}{*}{4.} & \multirow[t]{4}{*}{ Presentation } & $\begin{array}{l}\text { Augmented Reality (AR) media } \\
\text { is easy to operate }\end{array}$ & 4,20 & 5,00 & 84,00 & Very interesting \\
\hline & & $\begin{array}{l}\text { Augmented Reality (AR) media } \\
\text { is interesting }\end{array}$ & 4,60 & 5,00 & 92,00 & Very interesting \\
\hline & & Average & $\mathbf{4 , 4 0}$ & 5,00 & 88,00 & Very interesting \\
\hline & & Average Total & 4,44 & 5,00 & $\mathbf{8 8 , 8 0}$ & Very interesting \\
\hline
\end{tabular}

According to Table 5, the results obtained from the student response questionnaire to determine the interisting of the media with the average obtained is $88.80 \%$ with the criteria from score very interesting. The material aspects of the material criteria for Augmented Reality (AR) clearly get an average $80 \%$ with get the criteria Interesting. In the data above, the highest average value is found in the language aspect with an average $94 \%$ to the criteria very interesting and then the lowest average value is in the display aspect, namely with value of $85 \%$ the criteria very interesting. Looking at the display aspect that gets the lowest average value, there is a need for improvement, namely regarding the appearance and the Augmented Reality (AR) media to make it more attractive.

\section{Evaluation}

Evaluation results aim to obtain the value of an object which is carried out through use, processing data and collecting relevant information. (Pribadi, 2016) states that evaluation can also be interpreted as a systematic process that can be carried out in an attempt to design, collect, report, and also apply information to decide the value and use of objects. The evaluation stage is carried out to find out a product that is relevant and feasible for use as a medium in learning activities.
This stage is the research stage of the product after being tested by expert lecturers and students. From this evaluation stage, it can be concluded that the development of Augmented Reality media is very feasible and very interesting to be used as media/material in learning activities.

\section{CONCLUSIONS AND SUGGESTIONS}

\section{CONCLUSION}

The Overall, the results of media development through the validation of media experts and material experts are development of Augmented Reality (AR) media on bee metamorphosis is declared feasible to be used in learning activities. The results of media expert validation get $80 \%$ with fesiable criteria, then material expert validation get a percentage of $88 \%$ with very feasible criteria. The results of user trials (students) conducted to determine the attractiveness of AR media with a percentage of $88.75 \%$ very feasible criteria. So that in the development of Augmented Reality (AR) media on bee metamorphosis, declared feasible to be used as learning support, teaching materials, and learning references. 


\section{SUGGESTION}

1. Augmented Reality (AR) media was further developed to cover some metamorphosis material, not only bees.

2. The appearance of Augmented Reality (AR) media is made more attractive so that students don't get bored.

3. The size of the video / image in Augmented Reality (AR) is made according to the screen of the cellphone, so that when the cellphone is moved away or near it has no effect.

4. It is hoped that the Augmented Reality (AR) media can be distributed via Android, because the images use real photos, the Augmented Reality media in this bee metamorphosis can be used for various levels of school, from Elementary School to Higher Education and even for the general public. Henceforth, the writer will try to distribute it to Google Play so that students can also use it themselves.

\section{REFERENCES}

Ahmadi., R., A., dkk, 2017. Teknologi Augmented Reality Sebagai Media Pembelajaran Gerakan Shalat. Prosiding Seminar Nasional Komputer dan Informatika (SENASKI) 2017 (ISBN: 978602-60250-1-2)

https://ojs.unikom.ac.id/index.php/senaski/ article/view/940

Asyhar, R. (2012). Kreatif Mengembangkan Media Pembelajaran. Penerbit: Jakarta Referensi.

Arsyad, A. (2010). Media Pembelajaran. Penerbit: PT Raja Grafindo Persada Jakarta.

Campbel, N. A \& J. B. Reece. (2010). 3. Biologi: Edisi Kedelapan Jilid 3. Terjemahan: Damaring Tyas Wulandari. Jakarta: Erlangga

Khairudin, Muhammad. 2016. Pengembangan Modul Pembelajaran Ipa Biologi Berbasis Inquiry Pada Materi Interaksi Antar Makhluk Hidup Dengan Lingkungannya. Jurnal Pendidikan Biologi Universitas Muhammadiyah Metro, Vol. 7, No. 2.

Mahmun,. Nunu. (2012). Media Pembelajaran (Kajian Terhadap Langkah-Langkah pemilihan Media dan Implementasi Dalam Pembelajaran). Jurnal Pemikiran Islam. Vol.37 No. 1 Januari - Juni.

Meishanti, OPY. 2018. Pelibatan Aktor Pendidikan Dalam System Three Way Traffic Communication Untuk Meningkatkan Mutu Peserta Didik Sekolah Dasar Di Jombang. Jurnal Akrab Juara. $\begin{array}{llll}\text { Volume } & 3 & \text { Nomor } & 1\end{array}$ http://akrabjuara.com/index.php/akrabjuara /article/view/140

Meishanti, OPY. 2020. Analisis Keterlaksanaan Praktikum Biologi Terhadap Hasil Belajar Psikomotor Peserta Didik Kelas XI IPA di MA Al Ihsan Tembelang Jombang. Jurnal Eduscope (online). VOL. 6, No. 1, http://ejournal.unwaha.ac.id/index.php/edu scope/article/view/874/433 diakses 31 Oktober 2020

Mustika, D. 2015. Implementasi Augmented Reality Sebagai Media Pembelajaran Interaktif. Citec Journal, 2(4): 277-290.

Mustaqim, I. 2016. Pemanfaatan Augmented Reality Sebagai Media Pembelajaran. Jurnal Pendidikan Teknologi dan Kejuruan, (Online), Vol 13, No. 2, (https://ejournal.undiksha.ac.id/index.php/ JPTK/aticle/view/8525, diakses $11 \mathrm{Mei}$ 2019).

Peraturan Menteri Pendidikan Dan Kebudayaan Nomor 22 Tahun 2016 Tentang Standar Proses Pendidikan Dasar Dan Menengah.

Permana, R. H. (2019). Survei Kualitas Pendidikan PISA 2018: RI Sepuluh Besar dari Bawah. (online). (https://m.detik.com/news/berita/d4808456/survei-kualitas-pendidikan-pisa2018-ri-sepuluh-besar-dari-bawah)

Pribadi, Dr, Benny A. 2016. Desain dan Pengembangan Program Pelatihan Berbasis Kompetensi: Implementasi Model ADDIE. Jakarta: Prenada Media Group.

Riduwan. 2012. Belajar Mudah untuk Penelitian Guru Karyawan dan Peneliti Pemula. Bandung: Alfabeta.

Saputro., R., E., dan Saputra., D.,I.,S. 2015. Pengembangan Media Pembelajaran Mengenal Organ Pencernaan Manusia Menggunakan Teknologi Augmented Realit. Jurnal Buana Informatika, Volume 6, Nomor 2, April 2015: 153-162 https://ojs.uajy.ac.id/index.php/jbi/article/v iew/404/452

Sugiarta, I.M, dkk. 2019. Filsafat Pendidikan Ki Hajar Dewantara (Tokoh Timur). Jurnal Filsafat Indonesia, Vol 2 No 3 Tahun 2019 ISSN: E-ISSN 2620-7982, P-ISSN: 26207990.

https://ejournal.undiksha.ac.id/index.php/J FI/article/view/22187

Tim Dosen Jurusan Administrasi Pendidikan. 2008. Manajemen Pendidikan. Bandung: Alfabeta.

Young, J. C. 2015. Marketing Communication Menggunakan Augmented Reality. ULTIMATICS, 7(1): 14-15 